\title{
Chronic Energy Malnutrition and Anemia in Pregnant Women in Medan
}

\author{
Zulhaida Lubis ${ }^{1}$, Jumirah ${ }^{2}$, Maya Fitria ${ }^{3}$ \\ ${ }_{1,2}$ Department of Public Health Nutrition, Faculty of Public Health University of Sumatera Utara, Indonesia \\ idaulinasegmail.com \\ jumirahf@yahoo.com \\ ${ }^{3}$ Department of Biostatistic and Population, Public Health University of Sumatera Utara, Indonesia \\ fitriamaya78@gmail.com
}

\begin{abstract}
Chronic energy malnutrition (CEM) and anemia in pregnancy may affect the weight of babies born will have an impact on the quality of human resources. Anemia in pregnant women potentially endanger the mother and child and to this day it happened is still high in Indonesia, because that CEM and anemia require serious attention of all parties involved in health care. This study aims to determine the magnitude of the problem of anemia and chronic energy malnutrition (CEM) in pregnant women and analyze the relationship between CEM with the incidence of anemia in pregnant women in Medan. This study included a survey explanatory research with cross sectional design, conducted in four working area of community health centers in Medan (Belawan, Pekan Labuhan, Medan Deli and Terjun) on 114 pregnant women. CEM is determined by measuring the Upper Arm Circumference (MUAC). Blood hemoglobin concentration was measured by a "Hemoglobin Testing System: Quik-Check", plus the characteristic data of pregnant women (age, gestational age, pregnancy spacing, and parity) was obtained by questionnaire interviews. The results showed that of 114 pregnant women with $14,0 \%$ was aged $<20$ years, $42.1 \%$ in the 2 nd trimester of gestation and $47.4 \%$ trimester $3.52 .6 \%$ of pregnant women with pregnancy spacing $<24$ months and $272 \%$ parity $>=3$. Chronic energy malnutrition (CEM) in pregnant women was $23.7 \%$ and $44.7 \%$ anemia. Chi square analysis results obtained significant relationship between CEM with anemia in pregnant women with OR of $4.08295 \%$ CI 1.604 to 10.387. This shows that pregnant women who are at risk of anemia CEM four times greater compared with pregnant women who are not CEM. There was a significant correlation between anemia and CEM, and CEM was a risk factor for anemia in pregnant women in Medan. Thus one of the efforts that need to be done in the context of prevention of anemia of pregnant women in Medan is to reduce the incidence of CEM. Improvements nutrition not only during pregnancy but before the mother into their pregnancy, so that mothers begin pregnancy at a good nutritional condition.
\end{abstract}

Keywords - Chronic Energy Malnutrition (CEM), anemia, pregnant women.

\section{INTRODUCTION}

Iron deficiency anemia is the most prevalent type of nutritional problems in the world which has afflicted about 2 billions of people. However, the extent to which it is required depends on age, sex and physiological status. For example pregnant women require higher amounts of iron due to an increased blood volume and the growth of the fetus, placenta and other body tissues [1]. In Indonesa, anemia in pregnancy is a national problem because it reflects the value of socio-economic welfare of society, and has had enormous influence on the quality of human resources. Anemia in pregnant women called "potential danger to mother and child" (the potential harm to the mother and child), because that's anemia requires serious attention from all parties involved in health care [2].

The high maternal anemia affecting negatively impact on the fetus, childbirth and the postpartum and babies born with low birth weight (LBW), preterm parturition, abortion, postpartum hemorrhage, obstructed labor. This is related to many factors, among others, age, parity, education, employment, and knowledge [3].

Insufficient or inadequate food intake be it from lack of quantity or lackof essential nutrients including protein and specific micronutrients remains a blight across the developing world. Undernutrition can have effects throughout the life cycle. Physical stunting (defined by the WHO as low height-for-age) can affect cognitive development, increase susceptibility to infection, and impair school attainment and future productivity of survivors as well as of later generations [4].

Besides the problem of anemia, chronic energy malnutrition (CEM) is also a problem that is common in women of childbearing age, pregnant women Including. Data basic health research in Indonesia in 2013 showed that the number CEM 24.2 percent in pregnant women [5]. When mothers lack 
of energy and protein intake usually mothers also lack other nutrients including vitamins and minerals, so that mothers are also at risk of micronutrient deficiencies, including iron and folic acid which allows mothers are anemic. North Sumatra Province Health Office report in 2014 the incidence of anemia among pregnant women in North Sumatra 28.7\%, which is caused by pregnant women are insufficient intake of iron include iron tablets [6].

Based on those background, this study aims to describe the prevalence of anemia and to analyze the relationship between chronic energy malnutrition with the incidence of anemia among the pregnant women in Medan city.

\section{METHODS}

This is the explanatory research by cross-sectional design. The research conduct in Medan, community health center named Puskesmas Belawan (Medan Belawan Subdistrict), Puskesmas Terjun (Medan Marelan Subdistric), Puskesmas Pekan Labuhan (Medan Labuhan Subdistric), Puskesmas Medan Deli (Medan Deli Subdistrict).

The population in this study were all pregnant women in the work area of those community health center. Sampling by the formula to research an analytical survey of the population of categorical data [7].

$$
\begin{aligned}
& n=\frac{\left\{z_{1-\alpha} \sqrt{p_{0}\left(1-p_{0}\right)}+Z_{1-\beta} \sqrt{P a(1-P a)}\right\}^{2}}{\left(P_{a}-P_{0}\right)^{2}} \\
& \alpha=5 \%, \mathrm{z}=1,96 \\
& \beta=10 \%, \mathrm{z}=1,282 \\
& \text { Po }=\text { estimate the proportion of anemia }=0,5 \\
& \text { Pa-Po }=15 \% \\
& \mathrm{n}=114
\end{aligned}
$$

In this study, 114 pregnant women were taken in four working areas of community health centers in Medan. Sampling techniques is the accidental sampling when the pregnant women came to visit the health centers in their respective working area health centers.

Data on maternal characteristics (age, gestational age, pregnancy spacing, and parity) obtained by interview using a questionnaire. Hb levels measured using $\mathrm{Hb}$ "Quik-Check" and the incidence of chronic energy malnutrition (CEM) measured by circumference of the upper arm. Analysis of the relationship of chronic energy malnutrition with anemia done with chi square test.

\section{RESULT and DISCUSSION}

Table 1 it can be seen the characteristics of pregnant women which showed that $86.0 \%$ of pregnant women were 20-35 years of age, gestational age at most on the trimester III, pregnancy spacing as much as $52.6 \%<24$ months, and $72.8 \%$ less than 3 parity.

TABLE I

THE FREQUENCY DISTRIBUTION PREGNANT WOMEN CHARACTERISTICS (AGE, GESTATIONAL AGE, SPACING PREGNANCIES AND PARITY)

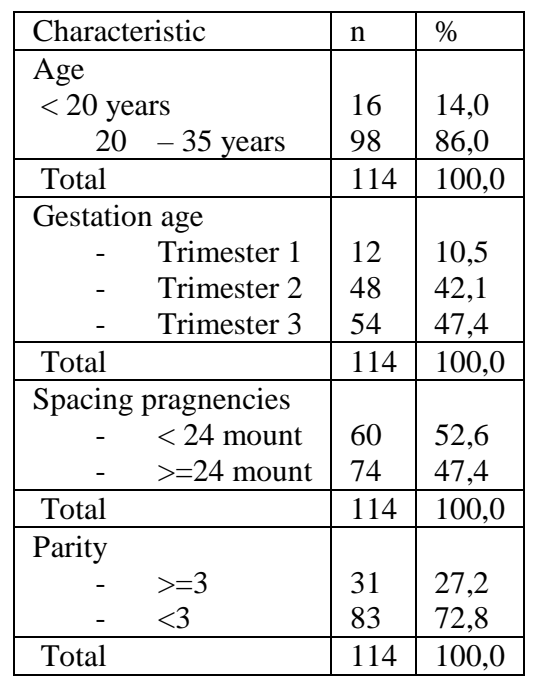

Table 2 shows 27 people $(23,7 \%)$ pregnant women suffer from chronic energy malnutrition (KEK). This figure is slightly below the average chronic energy malnutrition in pregnant women in Indonesia that is $24,2 \%$ and above the number of chronic energy malnutrition in women of childbearing age that is $20,8 \%$ [8].

TABLE II

FREQUENCY DISTRIBUTION OF CHRONIC ENERGY MALNUTRITION (CEM) IN PREGNANCY

\begin{tabular}{|l|c|c|}
\hline Incidence & $\mathrm{n}$ & $\%$ \\
\hline CEM & 27 & 23,7 \\
\hline Normal & 87 & 76,3 \\
\hline Total & 114 & 100,0 \\
\hline
\end{tabular}


The incidence of anemia was measured based on levels of Hemoglobin $(\mathrm{Hb})$ of pregnant women, with the criteria of the levels of $\mathrm{Hb}$ is less than $11 \mathrm{mg} / \mathrm{dl}$ [8]. The results of the examination of Hb levelsfound that pregnant women who experience anemia as much as 51 people $(44.7 \%)$ which can be seen in Table 3. Numbers of anemic pregnant women in the study was far above the average of women's anemia in Indonesia based on the results of the Riskesdas (2013) that is $24 \%$. While St. Fatima, et al's research result in South Sulawesi Maros found the incidence of anemia in pregnant women as much as $41 \%$ [9].

TABLE III

FREQUENCY DistributionOF ANEMIA INCIDENCE IN PREGNANT WOMEN

\begin{tabular}{|l|l|l|}
\hline Incidence & $\mathrm{N}$ & $\%$ \\
\hline Anemia & 51 & 44,7 \\
\hline
\end{tabular}

\begin{tabular}{|l|l|l|}
\hline Normal & 63 & 55,3 \\
\hline Total & 114 & 100,0 \\
\hline
\end{tabular}

A. Relationship of Chronic Energy Malnutrition and Anemia in Pregnant Women

Relationship between chronic energy malnutrition and anemia was analized statistically by chi square test. The relation result can be seen in Table 4 . It shows $70.4 \%$ mothers who experience chronic energy malnutrtion (CEM)is anemic. Chi square analysis results indicated that CEM has a significant relationship with the incidence of anemia in pregnant women $(\mathrm{OR}=4.082)$. It means the risk of pregnant women who experience CEM is 4 times greater to be anemia compared to mothers who are not CEM or normal.

TABLE IV

RELATIONSHIP OF CHRONIC ENERGy MALNUTRITION (CEM) AND ANEMIA IN PREGNANT WOMEN

\begin{tabular}{|c|c|c|c|c|c|c|c|c|c|}
\hline \multirow{2}{*}{ CEM incidence } & \multicolumn{2}{|c|}{ Anemia } & \multicolumn{2}{c|}{ Normal } & \multicolumn{2}{c|}{ Total } & \multirow{2}{*}{ P } & OR & CI \\
\cline { 2 - 9 } & $\mathrm{n}$ & $\%$ & $\mathrm{n}$ & $\%$ & $\mathrm{n}$ & $\%$ & & & \\
\hline Yes & 19 & 70,4 & 8 & 29,6 & 27 & 100.0 & 0,002 & 4,08 & $1,604-10,387$ \\
No/Normal & 32 & 36,8 & 55 & 63,2 & 87 & 100,0 & & & \\
\hline
\end{tabular}

Pregnant women who experience CEM describe the condition of very low dietary energy and protein especially, so the availability of nutrients in the body including a decrease in fat reserves.

When the mother suffered a lack of energy and proteins, usually the mothers experienced the lack of other nutritional intake too including vitamins and minerals, it means those at-risk mothers experience lack of a variety of micro nutrients including iron and folic acid, that allows the motherbecome anemia. The results of this study in accordance with research of St. Fatima, et al. that shows that the levels of hemoglobin of pregnant women was associated with significant maternal nutritional status (LILA), consumption of iron tablets and meal consumption patterns on expectant mothers in South Sulawesi Maros [9].

Atiek Zahruliansyah [10] in a review article about anemia and eating habits of pregnant women in Indonesia said that the incidence of anaemia in pregnant women is closely related to economic and cultural factors. The cultural factors such as the presence of food abstinence for pregnant mothers, and fathers in the family always gets the priority of the food, so it was common to mothers experiencing nutritional deficiencies. The other factors that also play a role is the knowledge of mothers and families about the importance of nutrition and foods that are good for women of fertile age, moreover for pregnant women.

Thus, one kind of effort to improve the nutritional status of the mother is through increased knowledge of nutrition and health. Improvement of knowledge is expected to improve the attitude and actions of the mother in food consumption so with the good eating pattern the mother will avoid anemia.

\section{CONCLUSION}

Chronic energy malnutrition is related significantly and become a risk factor of anemia in pregnant women. Risk of pregnant women with chronic energy malnutrition is 4 times higher than pregnant women without chronic energy malnutrition. Based on the results of this study, to reduce the numbers of anemia in pregnant women especially in Medan, the nutritional intake of pregnant women can be improved, even should be 
noted before the pregnancy so the mothers who start pregnancy are on the adequacy of good nutrition.

\section{REFERENCES}

[1] Turaj Kazemi. 2014. A Review of Iron Deficiency Anemia. Review Article. Journal Of Current Research In Science (Issn 2322 -5009) Coden (Usa): Jcrsdj 2014, Vol. 2, No. 6, Pp: 882-886

[2] Manuaba, et al. 2010. Ilmu Kebidanan Penyakit Kandungan Dan Keluarga Berencana Edisi 2. Jakarta. EGC.

[3] Prawirohardjo Sarwono. 2009. Ilmu Kebidanan. Jakarta : Yayasan Bina Pustaka Sarwono Prawirohardjo.

[4] Samuelina S. Arthur, Bongiwe Nyide, Abdramane Bassiahi Soura Kathleen Kahn, ark Weston and Osman Sankoh. Tackling malnutrition: a systematic review of 15-year research evidence from INDEPTH health and demographic surveillance systems. Citation: Glob Health Action 2015, 8: 28298 http://dx.doi.org/10.3402/gha.v8.28298

[5] Kemenkes RI. 2013. Riset Kesehatan Dasar. Badan penelitian dan pengembangan kesehatan RI. Jakarta.

[6] Dinkes Propinsi Sumatera Utara. 2014. Profil Kesehatan Propins Sumatera Utara. Medan

[7] Bisma Murti. 2015. Desain dan Ukuran Sampel Untuk Penelitian Kuantitatif dan Kualitatif Di Bidang Kesehatan. Gajah Mada University Press. Yokyakarta

[8] WHO. 2011. Haemoglobin Concentration for the Diagnosis if Anaemia and Assessment of Severity. Word Health Organization. Geneva

[9] St. Fatimah1, Veni Hadju, Burhanuddin Bahar, Zulkifli Abdullah. 2011. Pola Konsumsi Dan Kadar Hemoglobin Pada Ibu Hamil Di Kabupaten Maros, Sulawesi Selatan. Makara, Kesehatan, Vol. 15, No. 1, Juni 2011 : 31-36

[10] Atiek Zahrulianingdyah. 2016. Review Article. The Contribution of Indonesian Women's Eating Habit to Iron Deficiency Anemia. Pak. J. Nutr., 15 (11): 1003-1007, 2016 